\title{
技術報告
}

\section{JSK 超精密継手の試験}

\author{
久保 富夫*。宮下 直也**.石丸肇*
}

(昭和63年 5 月 16 日 受理)

\begin{abstract}
Testing of JSK Hi-precision Joint
Tomio KUBO*, Naoya MIYASHITA** and Hajime ISHIMARU*

* (National Lab. for High Energy Physics 1-1 Oho, Tsukuba-shi, Ibaraki-ken 305)

**(Sanko-Kogyo Co., Ltd. 2-22-13, Yaguchi, Ohta-ku, Tokyo 146)
\end{abstract}

(Received May 16, 1988)

1. 序

超高真空や超清浄ガス配管用の小型継ぎ手のアルミニ ウム合金化漈して，ステンレス鋼の小型継ぎ手の中で 最も良いものを選定しようと考えた。鏡面とへリコフレ ックスの組み合わせのフランジやバルブはすでに研 究1,2)されていた. JSK (Joint of Sanko Kogyo) 超精密継 ぎ手はスラストボールベアリングを使用して, 袋ナット とスリーブとの間の摩擦力を極力隇らしたこと,および ヘリコフレックスタイプのガスケットと鏡面シールの組 み合わせに特徵がある。ガスケットに内蔵されたコイル スプリングが接続部で二重になっていないため締め付け 時に当たり面に対しガスケットの外被覆が均一飞締め付 けられ安定した気密特性を得ることも特徵になってい る.このため袋ナット締め付け時に配管がねじられるこ とがない利点があり，またガスケット表面でこすれが起 こらず傷の発生がないため気密特性の高信頼性が期待で きる. 比較参考のため他のメ一カの製品, MCG (Metal G-ring Gasket)-1/4, 3/8および VCR（米国ケジョン社の 登録商標) $-1 / 4,3 / 8$ にいても試験した。

\section{2. 継ぎ手の構造}

JSK 超精密継ぎ手の構造を Fig. 1 亿示す。ボールベ アリングはスラストタイプになっており, 袋ナットとは 独立になっている．またへリコフレックス方式のガスケ ット（日本バルカーのトライパック）に内蔵されたスプ

\footnotetext{
* 高エネルギー物理学研究所 (茨城県つくば市大穂1-1)
}

** 三興工業株式会社（東京都大田区矢口2-22-13）



Fig. 1 Structure of JSK joint. 1. Piece with thrust bearing, 2. Main body, 3. Gasket-Tripack, 4. Cup nut.

リングの接続部において螺旋巻きのピッチを変えずに細 線同士で溶接されている. MGGはへリコフレックスタ イプのガスケット（内蔵されたコイルスプリングは接続 部で，スプリングの端部に他端の外径を小さくしたスプ リングをはめ込み二重になっている）とスリーブに直接 埋め込まれたボールベアリングを，VGRは平型金属ガ スケットを使用し，ボールベアリングは使用していない ことを特徵としている.

\section{3. 試 験方法}

評価試験は下記の 4 項目について行った.

1）締め付けトルクとガスケットの圧縮量との関係を 測定する.

2）規定の締め付けに必要なトルクとその時のガスケ 

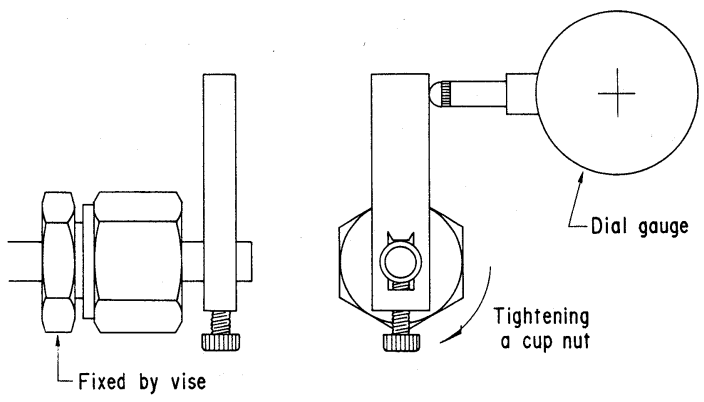

Fig. 2 Schematic diagram for torsion test of piece during tightening of a cup nut.

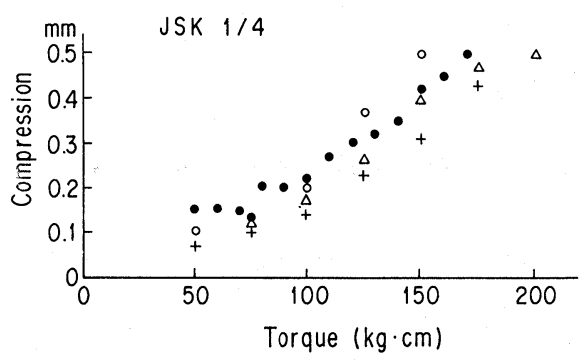

(a)

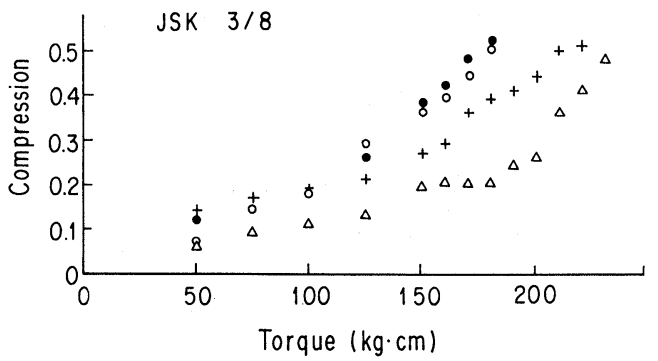

(b)

Fig. 3 Tightening torque vs. compression of gasket. a. JSK $-1 / 4$, b. JSK $-3 / 8$.

ットの圧縮量を測定する.

3）ヘリウムリーク試験器を使用してリークの有無を 調ベる。

4）締め付け時にスリーブにねじれの発生の有無を調 ベる.この測定は Fig. 2 に示すよらにピースに約 $50 \mathrm{~mm}$ の腕木を付けてねじれによって発生する変 位をダイヤルゲージで観測する。

評価試験のサンプル数は下記とした.

$\begin{array}{lr}\text { JSK-1 } / 4 & 30 \text { 個 } \\ \text { JSK-3 } / 8 & \text { 15個 } \\ \text { MCG-1 } / 4 & 3 \text { 個 }\end{array}$

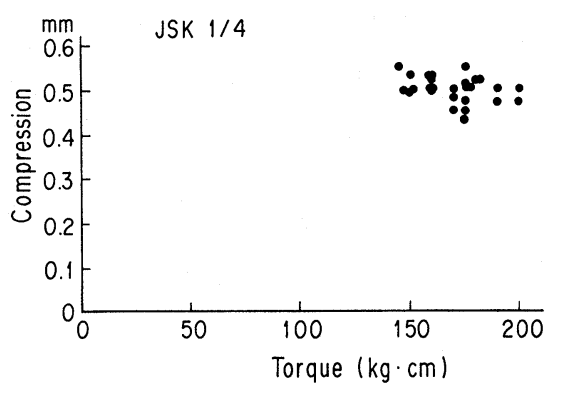

(a)

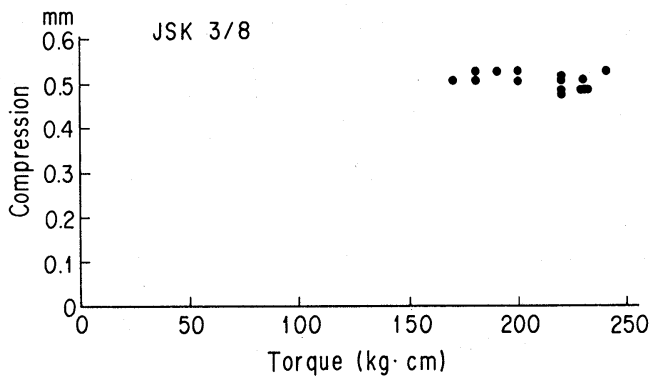

(b)

Fig. 4 Tightening torque vs. compression of gasket after tightening. a. JSK $-1 / 4$, b. JSK $-3 / 8$.

$\begin{array}{ll}\mathrm{MCG}-3 / 8 & 3 \text { 個 } \\ \mathrm{VCR}-1 / 4 & 3 \text { 個 } \\ \mathrm{VCR}-3 / 8 & 3 \text { 個 }\end{array}$

\section{4. 結果と考察}

評価試験は下記の 4 項目とした。

1)の締め付けトルクとガスケットの圧縮量の測定結果 を Fig. 3(a)，3(b)に示す。この測定は各々 4 個につい

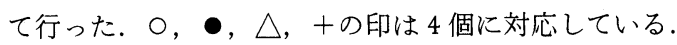
縦軸は圧宿量，横軸は締め付けトルクである．評価基準 は小さな締め付けトルクで大きな圧縮量が得られること である。グラフで締め付けトルクと圧縮量の直線性が良 いこと，右上がり線の勾配が大きいこととする．JSK 超精密継ぎ手の測定結果はいずれも良好であった. MCG-1/4 と VCR-1/4は規定のガスケットの圧縮量を 得る締め付けトルクはJSKとほぼ同じであったが， MCG-3/8 と VCR-3/8の大きいサイズではJSKに比較 して大きな值になった．ガスケットの圧縮量はへリコフ レックス型の JSK と MCG では内部にスプリングを内 蔵しているので大きな值を持ち，VGRは単なる金属平 型ガスケットであり，かなり小さい值となった．

2)の規定の締め付け完了時における締め付けトルクと ガスケット圧縮量の測定結果を Fig. 4(a)，4(b) に示す. 
Table 1 Summary of the evaluation test results for JSK, MGG and VGR joints

\begin{tabular}{llccc}
\hline \hline Items & Required torque & Compression of gasket & Torsion of piece & Aperture \\
\hline $\mathrm{JSK}-1 / 4$ & $145-200 \mathrm{~kg} \cdot \mathrm{cm}$ & $0.43-0.55 \mathrm{~mm}$ & No & $4.2 \mathrm{~mm} \phi$ \\
$\mathrm{MCG}-1 / 4$ & 150 & 0.5 & Yes & 4.5 \\
$\mathrm{VCR}-1 / 4$ & 145 & 0.18 & Yes & 3.1 \\
$\mathrm{JSK}-3 / 8$ & $170-240$ & $0.47-0.52$ & No & 6.9 \\
$\mathrm{MCG}-3 / 8$ & 450 & 0.45 & Yes & 7.2 \\
$\mathrm{VCR}-3 / 8$ & 420 & 0.18 & Yes & 8.1 \\
\hline
\end{tabular}

縦軸はガスケットの圧縮量，横軸は締め付けトルクであ る.JSK 継ぎ手は他の継ぎ手に比較して規定の圧縮量 に必要な締め付けトルクが小さかった。

3)のヘリウムリーク試験については比較参考品を含め てすべてへリウムリークは $10^{-10}$ Torr $l / \mathrm{s}$ 以下であった.

4)の袋ナット締め付け時におけるピースのねじれに関 して，MCG，VCR ともに袋ナットを締め付けるとピー スまでとも回りしてしまい，ストローク $10 \mathrm{~mm}$ のダイ ヤルゲージの測定範囲を越えた。JSK 超精密継ぎ手は ダイヤルゲージの目盛りで0.05 mm 以下でほとんど動 かなかった，測定結果を Table 1 にまとめた.

\section{5. 結 論}

ステンレス鋼製の JSK 超精密継ぎ手は，従来製品に
比較して必要な圧縮量を得る締め付トルクが格段に小さ かった．締め付けトルクが小さいことと関連して袋ナッ ト締め付け時にガスケットとシール面にこすれがなく， また配管がねじれず，配管施工の信頼性が一段と高くな った。ステンレス鋼製の JSK 継ぎ手をアルミニウム合 金化した結果，良好な特性が得られたが別の報告とした い.

\section{[文献 $]$}

1）酒井, 石丸, 堀越, 玉井 : 真空, Vol. 24, No. 4, 1981, 172-175

2）久保, 酒井, 石丸：真空, Vol. 26, No. 5, 1983, 432-434 